\section{THE WORONORA DAM, SYDNEY}

A $\mathrm{T}$ present four large dams serve the metropolitan I area of Sydney with its water supply. The Woronora dam, which is now nearly completed, is in the Upper Nepean catchment, and serves Sydney through a separate pipeline. This will greatly increase the margin of safety against any possible failure of supply to Sydney, which has a population of nearly a million and a half. The dam is a mass concrete structure with a crest length of $1,300 \mathrm{ft}$. According to the Commonwealth Engineer of May 1, it will be $217 \mathrm{ft}$. high above foundation level and will impound approximately 15,800 million gallons.

After completing the excavation in the river bed, a large number of deep holes were drilled in the floor of the cut-off trench and over the remainder of the foundations. Into these holes liquid cement was pumped to seal up any cracks or fissures in the underlying rock strata. The rock surface was then made spotlessly clean by means of compressed air and water jets, after which concreting was commenced.

The impounding of about 15,800 million gallons of water by the dam across the Woronora River will result in the submergence of one thousand acres of river valley. This area, originally heavily wooded, is being cleared to prevent pollution of the water. Trees are felled, the larger ones broken up by blasting, and the undergrowth is cut down. After a short interval for drying, a running fire is allowed to pass over the area to burn off the small branches and leaves. The remaining timbers are then stacked and burnt.

An inspection gallery runs longitudinally through the dam at a height of $60 \mathrm{ft}$. above the river bed. An additional gallery is being constructed along the rock foundation to the southern abutment where excavation has revealed very broken strata. The 36 -in. outlet pipes at the base of the dam are controlled at the upstream end by timber stopboards, emergency roller gates and penstocks. At the downstream end the outlets are connected to the 48-in. diameter steel delivery main which forms the Woronora pipeline, and are each controlled by a gate valve and a needle valve. A spillway channel, $30 \mathrm{ft}$. wide at the bottom and with a maximum depth of $150 \mathrm{ft}$., is being excavated through a spur to provide for the maximum flood discharge of 36,000 cusecs. This channel will be conerete built up to about flood level.

\section{APPOINTMENTS VACANT}

AppIrcatrons are invited for the following appointments on cr before the dates mentioned:

Head of the Chemistry and Applied Chemistry. Department $\rightarrow$ The Principal, Stockport College for Further Education, Stockpor (August 15).

LeCTURER IN MINING-The Registrar, University College, Nottingham (August 16).

Headmaster to re-open British School at Punta Arenas, ChileThe British Council, 3 Hanover Street, London, W.1 (endorsed 'Chile') (August 20).

English Master for the Grange School, Santiago, Chile-The British Council, 3 Hanover Street, London, W.1 (endorsed 'Santiago') (August 20).

LeCrorer in Mechanical Engineming at the School of Mines and Technology, Treforest-The Director of Education, County Hall, Cardiff (August 20)

Assistant Lecterer in Mathematios-The Registrar, The University, Manchester 13 (August 22).

LeCTURER iN EleCtrical ENGINEERING, and LeCTURERS IN PhYsics AND Mathematics-The Registrar, Loughborough College, Loughborough (August 23)

ASsistant to THE CHIEF EnginezR-The General Manager, Manchester Ship Canal Co., Ship Canal House, Manchester 2 (endorsed 'Personal') (August 25).
Director of EddCation-The Town Clerk to the Local Education Committee, Town Hall, St. Helens, Lancs. (August 25).

Chimf Education OfFICER-The Education Officer, The Town Hall, Chesterfield (August 26)

TRACHER (MAN OR WOMAN) WITH GOOD QUALIFICATIONS IN BIOLOGY PHYsics AND MaThematics-The Headmaster, Dartington Hall, Totnes, Devon.

Dietitian-The Food Supervisor, Royal Masonic Hospital, Ravenscourt Park, London, W.6.

Lecturer IN Mathematics-The Principal, Rugby College of Technology and Arts, 61 Clifton Road, Rugby.

Master for Sclende AND EngIneering SubJects-The Principal, Sheerness Technical Institute and Junior Technical School; Sheerness

\section{REPORTS AND OTHER PUBLICATIONS}

(not included in the monthly Books Supplement)

\section{Great Britain and Ireland}

The Journal of the Institute of Metals. Vol. 66, 1940. Edited by N. B. Vaughan. Pp. xxxii $+449+70$ plates. (London: Institute of Metals.) $[217$

Metallurgical Abstracts (General and Non-Ferrous). Vol. 7, 1940. Edited by N. B. Vaughan. Pp. xii +652. (London: Institute of
Metals.)

University of London. Report of the Principal on the Work of the University during the Year 1940-41. Pp.6. (London: University
of London.)
[237

Mines Department. Eighteenth Annual Report of the Safety in Mines Research Board, including a Report of Matters dealt with by the Health Advisory Committee, 1939. Pp. 34. (London: H.M. Stationery Office.) 18. net.

Annual Report of Gresham's School Natural History Society, 1941. Pp. 60. (Holt: Gresham's School.)

\section{Other Countries}

Hokkaidō Imperial University. Calendar 1940-1941. Pp. iii +203 (Sapporo: Hokkaidō Imperial University.)

Imperial College of Tropical Agriculture : Department of Mycology and Bacteriology. Memoir No 6: Notes on the Targer Fungi of Trinidad. By R. W. Rayner. Pp. 12. (Trinidad: Imperial College of Tropical Agriculture.) 18, net.

Bulletin of the American Museum of Natural History. Vol. 78, Art. 1: The Mammals of Angola, Africa. By John Eric Hill and T. Donald Carter. Pp. $211+17$ plates. (New York: American Museum of Natural History.)

The Biochemical Research Laboratories of the Franklin Institute

( Commemoration of the Iife and Work of Alexander Dallas Bache and Symposiurn on Geomatism. February 14-15, 1941. Pp. 119-35. (Philadelphia: American Philosophical Society.) 1.50 dollars. [187 Indian Lac Research Institute. Bulletin No. 39: Physical Chemistry of Resin Solutions, Part 1: Anomalous Solubility of Shellac and other Resins in Organic Solvents. By Santi Ranjan Palit. Pp. 8. 1 anna. Bulletin No. 40: A New Method of Preparing Hydrosols of Shellac and other Natural Resins and their Properties. By Sant Ranjan Palit. Pp. 6. 6 pies. Bulletin No. 41 : Physical Chemistry of Resin Solutions, Part 2: Nature of Resin Solutions in Organic Sol vents. By Santi Ranjan Palit. Pp. 8 . 1 anna. Research Note No. 22 Modification of Shellac and Shellac Components with Melamine and Formaldehyde. By Y. Sankaranarayanan and H. K. Sen. Pp. 4 Research Note No. 23: Shellac-Coaltar Moulding Powders. By M. Venugopalan and $\dot{H}$. K. Sen. Pp. 4. (Namkum: Indian Lac Research Institute.)

$[217$

Publications of the Observatory of the University of Michigan. Vol. 8, No. 8: Spectrographic Studies of Two Semi-regular Variable Stars, W Cygni and RS Cancri. By Dean B. McLaughlin. Pp. 107-122. (Ann Arbor, Mich.: University of Michigan.)

Instituto Nacional de Tecnologia. 0 côco babacú : e o problema do combustivel. Pelo S. Fróes Abren. Segunda eqição. Pp. 94. (Rio de Janeiro: Instituto Nacional de Tecnologia.)

The Wolf and Hirsch Hillman Building: University of the Witwatersrand, Johannesburg. A Brochure published on the Occasion of the Official Opening of the Building by the Prime Minister of th Union of South Africa, Field Marshal the Rt. Hon. J. C. Smuts, 18th June 1941. Pp. 16. (Johannesburg: University of the Witwaters-
rand.)

Bureau of Education, India. Proceedings of the Sixth Meeting of the Central Advisory Board of Education in India, held at Madra on the 11th and 12th January 1941. Pp. iit131. (Delhi : Manager of Publications.) 14 annas; 18. 3d. [257

Memoirs of the Geological Survey of India. Vol. 76, Water-Supply Paper No. 2, 1940: Tube-Wells in and around Calcutta. By N. C. Bose. Pp. ii +22 . (Calcutta : Geological Survey of India.) 12 annas
[ 857 1257 Indian Association for the Cultivation of Science. Annual Report for the Year 1940. Pp. 42. (Calcutta: Indian Association for the
Advancement of Science.)
[257

Annual Return of Statistics relating to Forest Administration in British India for the Year 1938-39 (with which is incorporated the Quinquennial Review ending 31 st March 1939). Pp. ili +56. (Delhi :
[287 